\title{
COBALT-BASED ALLOYS FOR SURFACING
}

\author{
R. ROSERT \\ RCT GmbH, Dresden, Germany. E-mail: reinhard.rosert@gmx.de
}

\begin{abstract}
Many modern steel structures are characterized by high mechanical properties of joints, as well as good corrosion resistance of the applied materials. Coating of base materials with selected mechanical properties using surfacing by flux-cored wire based on cobalt is a reliable way to obtain the desired combination of properties, such as corrosion and wear resistance. The advantages of flux-cored wires by providing a diverse chemical composition of the deposited metal, reliability and high efficiency are proved in many industrial applications. This article describes examples of using Co-based flux-cored wires in two different welding processes (surfacing using TIG and MIG method). Different slag systems of wires and their properties are presented. Moreover a comparison with other arc surfacing processes is made. On the specific examples the diversity of applications of flux-cored wire based on cobalt is shown. The influence of different parameters on surfacing process is discussed. 11 Ref., 4 Tables, 10 Figures.
\end{abstract}

Keywords: arc surfacing, metal flux-cored wire, cobalt base, production, alloying, standardization, properties, application

Production of Co-based flux-cored wires for surfacing. Flux-cored wires based on cobalt for surfacing are rolled. So far only the flux-cored wires with overlapping strip are known ( $\mathrm{Fi}^{-}$ gure 1).

Production of cobalt flux-cored wires of seamless type is not possible so far due to a lower degree of filling. The flux-cored wires based on cobalt are metal powdered ones (M-type). Unlike medium- and highly-alloyed flux-cored wires for surfacing of corrosion- and wear-resistant layers, which mainly consist of non-alloyed strip and highly-alloyed filling, the high-quality alloyed flux-cored wires based on cobalt are composed of pure cobalt and filler containing alloying elements, deoxidizers, elements for stabilization of arc and slag-forming ones.

To achieve the accurate roundness of wire before its winding on the coil in manufacture after rolling stages the drawing is applied using accurate diamond dies. The principle of wire manufacture is shown in Figure 2.

The metal flux-cored wires provide a very finedrop metal transfer in surfacing and are characterized by absence of slag on the surface. The particles of manganese and silicate oxides located on the surface of the weld are easily removed. Except of high deposition rate using wires of M-type a significant penetration of base metal is achieved. These flux-cored wires can be used in all spatial positions. The use of pulsed technique is preferable. In general, the wires of M-type are surfaced in shielding gases according to the stand- ard DIN EN ISO 14175. Here, gases of the class 11 or M1x are applied. Cobalt flux-cored wires are also applied as a filler material in surfacing using non-consumable tungsten electrode (TIG method). In this case the wire feed can be realized in cold or preheated conditions. Moreover, fluxcored wires based on cobalt can be surfaced without shielding gas. In this case, the flux-cored wires belong to the type $U$. They are used for single and multipass surfacing in flat position. Filling of such wires consists of alloying elements, stabilizers of arc and also gas-forming elements, as well as slag-forming addition is possible.

Alloying groups. In Table 1 the conventional welding processes used for corrosion-resistant surfacing by cobalt flux-cored wires, types of protection and positions of surfacing are shown.

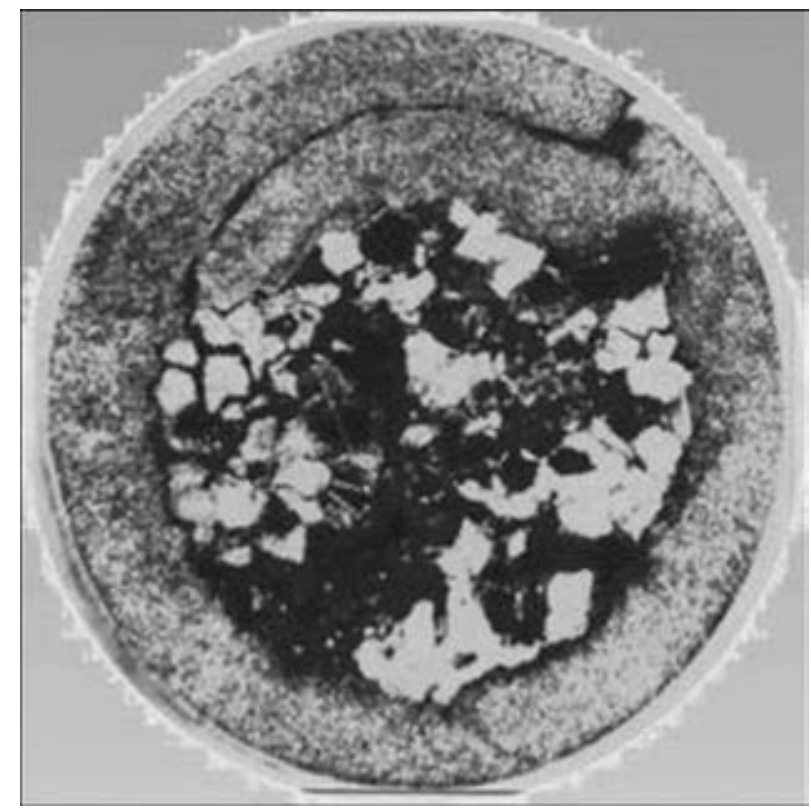

Figure 1. Rolled flux-cored wire with strip overlapping 


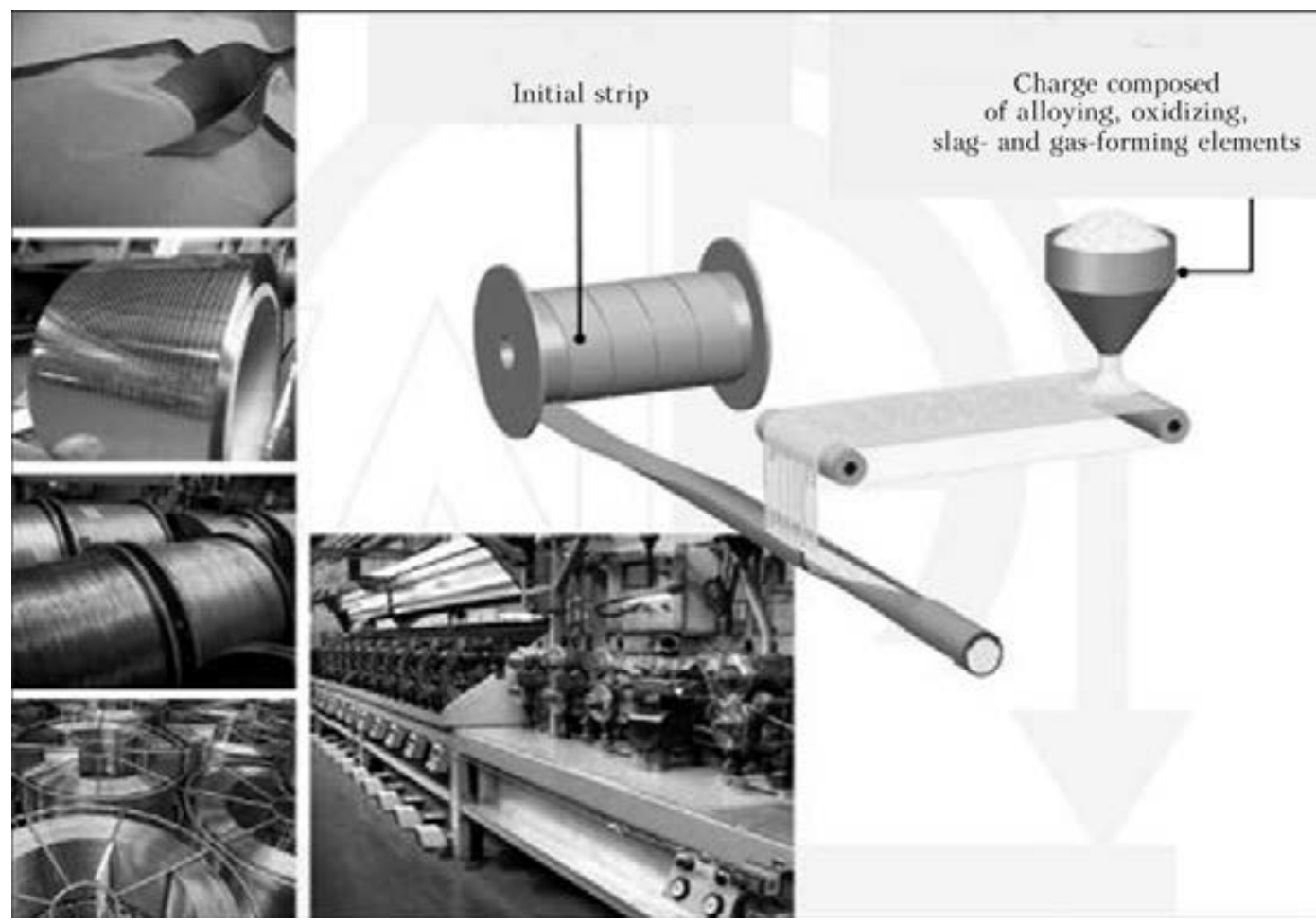

Figure 2. Production of Co-based flux-cored wires

Standard alloys. Table 2 the typical alloys are illustrated with hardness values of weld metal at the room temperature and up to $800^{\circ} \mathrm{C}$. Further the main fields of their application are shown. Today alloys 21 and 6 are among those, which are going to find the widest application in industry, in particular for surfacing of valve seats and sealing surfaces in oil or gas industry. These alloys possess an optimum combination of resistance to abrasion, corrosion and impact effects, at that, deposits have no cracks at strictly controlled surfacing parameters.

State-of-the-art of standardization. The international standardization (EN and ISO standards) as well as national regulations allows clas-

Table 1. Alloying groups

\begin{tabular}{||l|c|c||}
\hline \multicolumn{1}{|c|}{ Alloying group } & \multicolumn{2}{c||}{ Cobalt base } \\
\hline \multirow{2}{*}{ WA Cored Wires TM } & \multicolumn{2}{c||}{ STELLOY } \\
\cline { 2 - 3 } & $\mathrm{G}$ & $\mathrm{O}$ \\
\hline $\begin{array}{l}\text { Welding process acc. to } \\
\text { N ISO 4063 }\end{array}$ & 139 & 114 \\
\hline Welding process acc. to AWS & FCAW-G & FCAW \\
\cline { 2 - 3 } & FCAW-P & - \\
\hline AWS classification: & ERCCoxxx \\
Filler type & Eetal powder & Self-shielding \\
\cline { 2 - 3 } & M & U \\
\hline Welding position & PA & PA \\
\hline $\begin{array}{l}\text { Shielding gas acc. to } \\
\text { ISO 14175 }\end{array}$ & I1, M1x & - \\
\hline
\end{tabular}

sifying filler materials for surfacing. However, over flux-cored wires there is a special situation. Not for each alloying system the standard is available. Table 3 provides overview of state-of-theart of classification standards for arc surfacing.

Properties of surfacing coatings. Cobalt flux-cored wires are classified in the frames of materials for surfacing according to EN 14700 and in ASME II C SFA 5.21 even the standard materials for surfacing based on cobalt can be found.

Influence of technological parameters. Arc surfacing using flux-cored wire usually has a higher efficiency (up to $10 \mathrm{~kg} / \mathrm{h}$ or $0.4 \mathrm{~m}^{2} / \mathrm{h}$ ) as compared to solid wire electrodes, but has no their disadvantages in surfacing.

The penetration profile is similar to the profile in arc surfacing using electrodes. However the penetration depth can be reduced. In surfacing using cobalt flux-cored wires it is possible to control the penetration and thereby the iron content in the deposited layer (Figures 3 and 4).

It requires optimization of process parameters for surfacing using cobalt flux-cored wires.

The influence of technological parameters in arc surfacing using flux-cored wire can be described as follows:

- welding current: width and bead reinforcement as well as penetration are increased with increase in current strength;

- rate of surfacing: width and bead reinforcement are decreased with increase in welding 
Table 2. Typical standard alloys

\begin{tabular}{|c|c|c|c|c|c|c|c|}
\hline \multirow{2}{*}{ Type } & 1 & $6 \mathrm{BC}$ & 6 & $6 \mathrm{HC}$ & 12 & 21 & 25 \\
\hline & \multicolumn{7}{|c|}{ Wire diameter, mm } \\
\hline Stelloy-G MIG & $\begin{array}{l}1.2,1.6 \\
2.4\end{array}$ & $\begin{array}{l}1.2,1.6 \\
\quad 2.4\end{array}$ & $1.2,1.6,2.4$ & $1.2,1.6,2.4$ & $1.2,1.6,2.4$ & $1.2,1.6,2.4$ & $1.2,1.6$ \\
\hline Stelloy arc welding electrodes & $2.5-5.0$ & $\mathrm{~N} / \mathrm{A}$ & $2.5-5.0$ & $\mathrm{~N} / \mathrm{A}$ & $2.5-5.0$ & $2.5-4.0$ & $2.5-4.0$ \\
\hline Stelloy TIG wire & $\mathrm{N} / \mathrm{A}$ & $1.2-1.6$ & $1.2-1.6$ & $1.2-1.6$ & $\mathrm{~N} / \mathrm{A}$ & $1.2-1.6$ & $\mathrm{~N} / \mathrm{A}$ \\
\hline EN 14700 & TCo3 & $\mathrm{TCo} 2$ & TCo2 & TCo2 & TCo2 & TCo1 & TZCo1 \\
\hline $\begin{array}{l}\text { Typical chemical composition } \\
\text { of weld metal, wt. } \%\end{array}$ & $\begin{array}{c}\text { C } 2.3 \\
\text { Cr } 29 \\
\text { W } 12 \\
\text { Mn } 1.0 \\
\text { Si } 1.0 \\
\text { Fe } 4.0 \\
\text { Co - } \\
\text { base }\end{array}$ & $\begin{array}{c}\text { C } 0.9 \\
\text { Cr } 28.5 \\
\text { W } 4.5 \\
\text { Mn } 1.0 \\
\text { Si } 1.0 \\
\text { Fe } 4.0 \\
\text { Co }- \text { base }\end{array}$ & $\begin{array}{c}\text { C } 1.05 \\
\text { Cr } 28.5 \\
\text { W } 4.5 \\
\text { Mn } 1.0 \\
\text { Si } 1.0 \\
\text { Fe } 4.0 \\
\text { Co }- \text { base }\end{array}$ & $\begin{array}{c}\text { C } 1.2 \\
\text { Cr } 28.5 \\
\text { W } 4.5 \\
\text { Mn } 1.0 \\
\text { Si } 1.0 \\
\text { Fe } 4.0 \\
\text { Co }- \text { base }\end{array}$ & $\begin{array}{c}\text { C } 1.5 \\
\text { Cr } 30 \\
\text { W } 7.5 \\
\text { Mn } 1.0 \\
\text { Si } 1.0 \\
\text { Fe } 4.0 \\
\text { Co }- \text { base }\end{array}$ & $\begin{array}{c}\text { C } 0.25 \\
\text { Cr } 28 \\
\text { Mo } 5.5 \\
\text { Mn } 1.0 \\
\text { Ni } 3.0 \\
\text { Si } 1.0 \\
\text { Co }- \text { base }\end{array}$ & $\begin{array}{c}\text { C } 0.15 \\
\text { Cr } 20 \\
\text { W } 14 \\
\text { Mn } 1.5 \\
\text { Ni } 9.5 \\
\text { Si } 1.0 \\
\text { Fe } 4.0 \\
\text { Co }- \text { base }\end{array}$ \\
\hline $\begin{array}{l}\text { Hardness } H R C \text { of weld metal } \\
\text { at } 20{ }^{\circ} \mathrm{C} \\
\text { Hardness } H B \text { at } \\
200{ }^{\circ} \mathrm{C} \\
400{ }^{\circ} \mathrm{C} \\
600{ }^{\circ} \mathrm{C} \\
800{ }^{\circ} \mathrm{C}\end{array}$ & $\begin{array}{c}53 \\
495-560 \\
465 \\
420 \\
370 \\
330 \\
\end{array}$ & $\begin{array}{c}38 \\
350-380\end{array}$ & $\begin{array}{l}\text { Work hardens } \\
42 \\
380-415 \\
370 \\
320 \\
255 \\
240 \\
\end{array}$ & $\begin{array}{c}44 \\
410-430\end{array}$ & $\begin{array}{c}45 \\
415-455 \\
410 \\
370 \\
315 \\
275 \\
\end{array}$ & $\begin{array}{c}\text { Work hardens } \\
33 \\
300-340 \\
280 \\
255 \\
235 \\
220 \\
\end{array}$ & $\begin{array}{c}21 \\
210-260 \\
180 \\
145 \\
130 \\
120 \\
\end{array}$ \\
\hline Resistance to cracking & $*$ & $* * * *$ & $* * *$ & $* *$ & $* *$ & $* * * *$ & $* * * *$ \\
\hline Impact toughness & $*$ & $* * *$ & $* * *$ & $* *$ & $* *$ & $* * * *$ & $* * * *$ \\
\hline Metal-to-metal wear & $* * *$ & $* * *$ & $* * *$ & $* * *$ & $* * *$ & $* * * *$ & $* * * *$ \\
\hline Corrosion & $* * * *$ & $* * * *$ & $* * * *$ & $* * * *$ & $* * * *$ & $* * * *$ & $* * * *$ \\
\hline Wear in the cold state & $* * * *$ & $* *$ & $* * *$ & $* * *$ & $* * * *$ & $* *$ & $* *$ \\
\hline Wear in the hot state & $* * * *$ & $* *$ & $* * *$ & $* * *$ & $* * * *$ & $* *$ & $* * *$ \\
\hline Machining of the material & $* * * *$ & $* *$ & $* *$ & $* *$ & $* *$ & $* * * *$ & $* * * *$ \\
\hline
\end{tabular}

speed, penetration depth and degree of mixing with base metal are increased with increase in welding speed;

- arc length: penetration depth and degree of mixing with base metal are decreased with increase in length of the arc;

- torch position: with inclination of torch forward the penetration depth, degree of mixing with base metal and bead reinforcement are increased; with increasing the inclination angle of torch this effect is intensified, and width of the weld is reduced;

Table 3. Classification of standards for flux-cored wires

\begin{tabular}{|c|c|c|c|c|c|c|c|}
\hline \multirow[b]{2}{*}{ Standard } & \multicolumn{7}{|c|}{ Material } \\
\hline & $\begin{array}{l}\text { Low carbon and } \\
\text { low alloyed steels }\end{array}$ & $\begin{array}{l}\text { High strength } \\
\text { steels }\end{array}$ & $\begin{array}{l}\text { Heat-resistant } \\
\text { steels }\end{array}$ & $\begin{array}{l}\text { Stainless and } \\
\text { heat-resistant } \\
\text { steels }\end{array}$ & Nickel alloy & Cast iron & Hard alloys \\
\hline DIN & 8559 & - & - & - & - & 8573 & 8555 \\
\hline EN & 758 & 12535 & 12071 & 12073 & - & 1071 & $14700^{*}$ \\
\hline ISO & $17632^{*}$ & $18276^{*}$ & $17634^{*}$ & $17633^{*}$ & 12153 & $1071^{*}$ & - \\
\hline
\end{tabular}

- preheating: penetration depth, degree of mixing with base metal and weld width are increased with increase in preheating temperature, and bead reinforcement is reduced;

- shielding gas: the higher is content of $\mathrm{CO}_{2}$ in shielding gas, the greater is penetration depth and degree of mixing with base metal. The degree of mixing is increased by applying gases (without helium) in the following order: I1 < M13 < $<\mathrm{M} 12<\mathrm{M} 20<\mathrm{M} 21<\mathrm{CO}_{2}$.

Comparison of gas arc surfacing using cobalt flux-cored wire with other processes of surfac- 


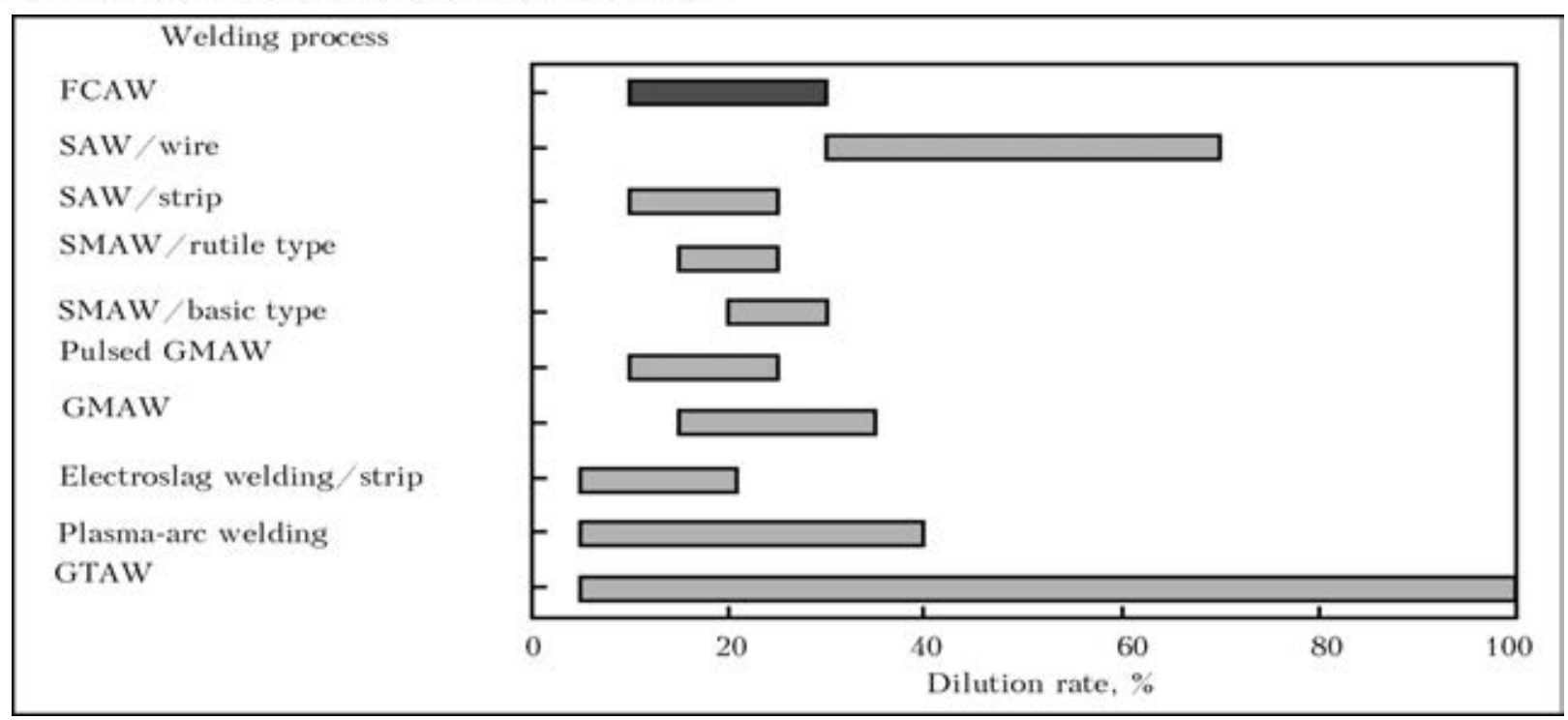

Figure 3. Penetration depth depending on method of surfacing

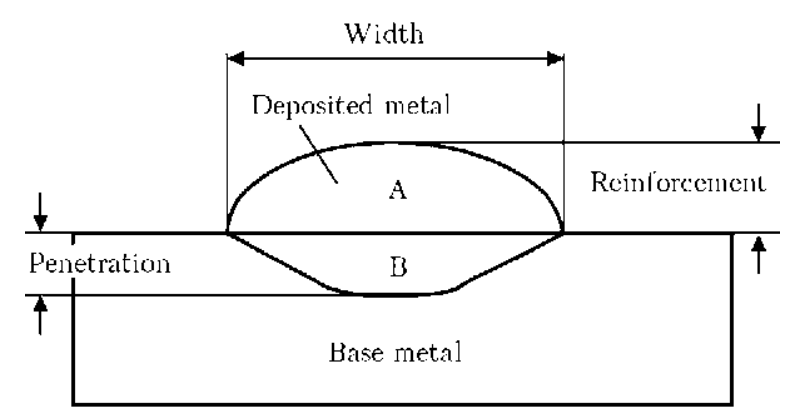

Stirring $[\%]=[\mathrm{B} /(\mathrm{A}+\mathrm{B})] \cdot 100$

Figure 4. Determination of penetration coefficient

ing. The arc surfacing using flux-cored wire has several advantages as compared to other processes of arc surfacing. They include low heat input; low deformation; poor mixing with base metal; possibility of single-layer surfacing; presence of great diversity of possible chemical compositions of deposited metal; possibility of surfacing in different spatial positions; low volume of further treatment.

Table 4 reflects the important distinctive criteria for different methods of surfacing. High purity of deposited metal using flux-cored wire based on cobalt is shown in Figure 5. This imaging shows the corresponding microstructure.

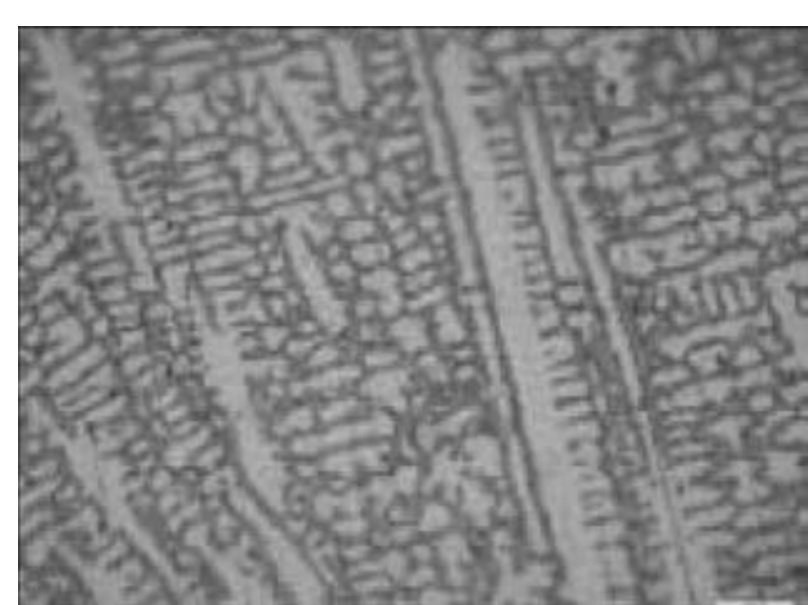

Figure 5. Microstructure of metal deposited using wire Stelloy $1-G$

Here it is noteworthy that dendritic structure is characterized by a very high purity.

Examples of application. The following examples demonstrate the variety of flux-cored wires based on cobalt. The alloys based on cobalt are used at high temperatures, where there is a high wear and corrosion resistance, for example, for high pressure sealing surfaces, screw conveyors of extruders in production of plastics, moulds in ceramic industry, tools in forge industry, hot

Table 4. Comparison of different surfacing methods

\begin{tabular}{|c|c|c|c|c|c|c|}
\hline Process & Automation & $\begin{array}{l}\text { Efficiency of } \\
\text { melting, } \mathrm{kg} / \mathrm{h}\end{array}$ & Investments & Welding positions & Advantages & Restrictions \\
\hline GTAW / hot wire & + & $1-2$ & High & All & High quality & Sizes/expenses \\
\hline GTAW / FCW & + & $3-5$ & Medium & All & Same & Efficiency \\
\hline GTAW / solid wire & + & $1-2$ & Same & $1 \mathrm{G} / 3 \mathrm{G}(\mathrm{PA}, \mathrm{PG})$ & Cost & Quality \\
\hline SMAW & - & $0.5-2$ & Low & All & Flexibility & $\begin{array}{c}\text { Possibility of } \\
\text { automation }\end{array}$ \\
\hline ESW & + & Up to 25 & High & $1 \mathrm{G}(\mathrm{PA})$ & $\begin{array}{c}\text { Price / kg of } \\
\text { deposited metal }\end{array}$ & Sizes \\
\hline
\end{tabular}




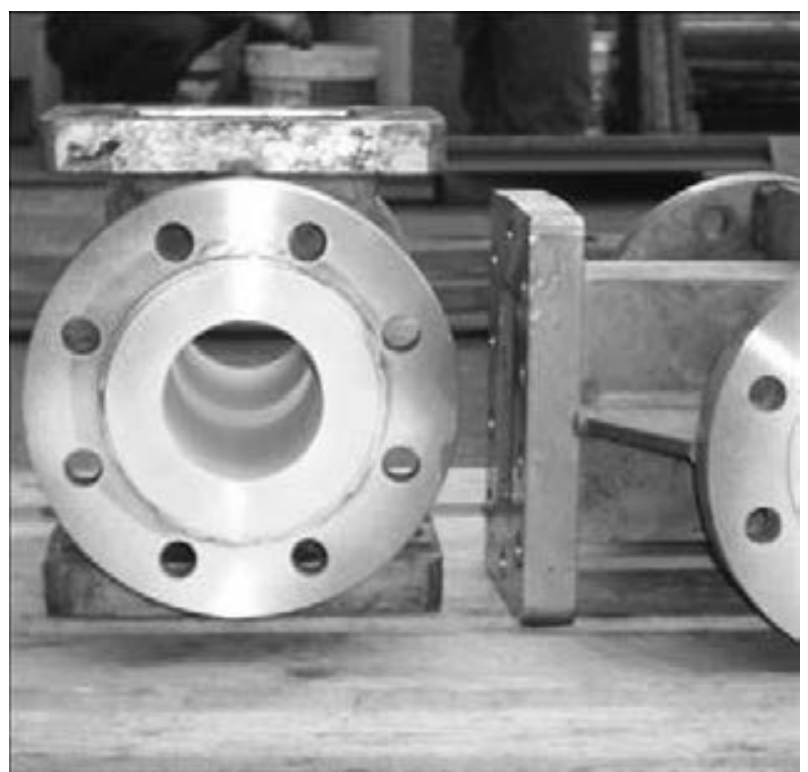

Figure 6. One-layer Hastelloy 6 coating produced using TIG method

shears or valves. For various alloys the corresponding flux-cored wires can be manufactured. They can be deposited using arc surfacing with or without using the pulsed technique. It is preferable to use pure argon as a shielding gas. In TIG surfacing as a shielding gas argon or mixture $\mathrm{Ar}+\mathrm{He}$ can be used.

Figure 6 shows TIG surfacing with Hastelloy 6 on valve seat. For a buffer layer in this case steel of 309L type can be used. Figure 7 shows MIG surfacing with Hastelloy G-6 for ceramic mould. Figure 8 shows single-layer arc surfacing using cobalt flux-cored wire of type Stelloy 21-G on the motor valve surface.

Another example of application of high-cobalt alloys can be brought from the steel industry. Hot knives cut steel rods and slabs at the temperature of $800{ }^{\circ} \mathrm{C}$. Due to a long contact with hot material the knives are exposed to thermal fatigue and it is necessary to protect them. Fi-

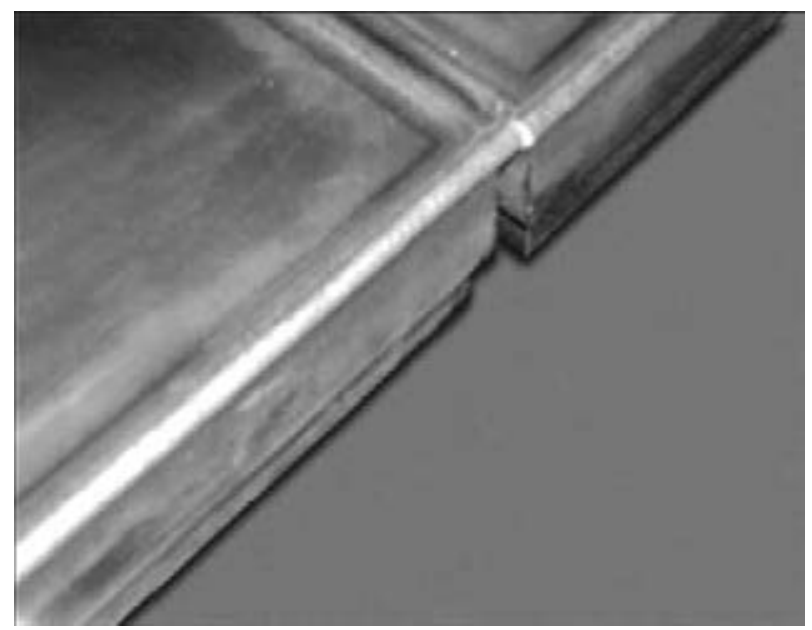

Figure 7. Surfacing of edges with alloy Hastelloy G-6

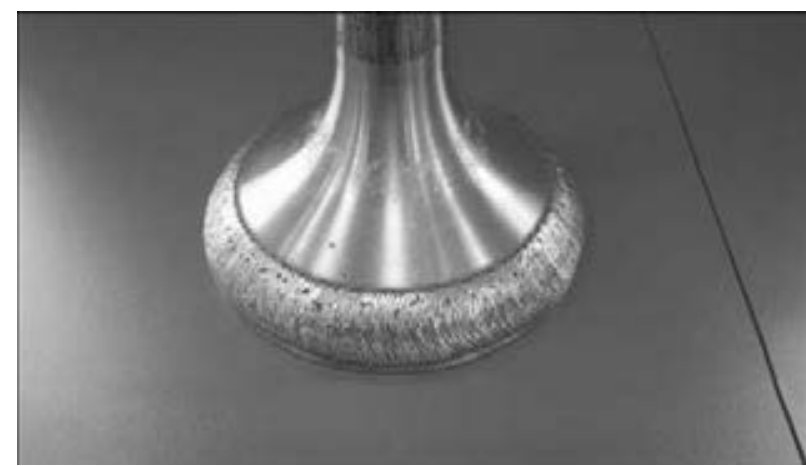

Figure 8. Surfacing of valve with alloy Stelloy 21-G

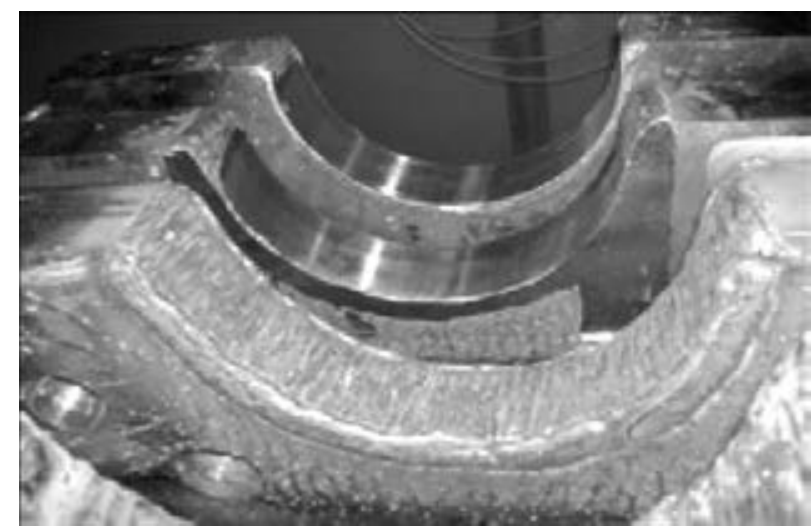

Figure 9. Multilayer surfacing of knife blade for hot cutting

gure 9 shows a typical multi-layered surfacing on hot cutting knife. After surfacing the heat treatment and subsequent machining are carried out.

Thermal conditions in surfacing using cobalt flux-cored wires. In most cases, the main criterion for producing high quality coating of $\mathrm{Co}^{-}$ based alloy is producing of deposits without cracks and with high hardness. The hardness of pure metal is in the range $H R C 21-53$ for standard alloys (see Table 2). At such a high hardness it is necessary to provide special measures to control heat input. First of all, the temperature of preliminary and interlayer heating must be strictly controlled and constantly maintained. The preheating depends on the type of base material, number of layers, thickness of walls.

As a rule, cobalt flux-cored wires of type 6 are deposited with preheating of not less than

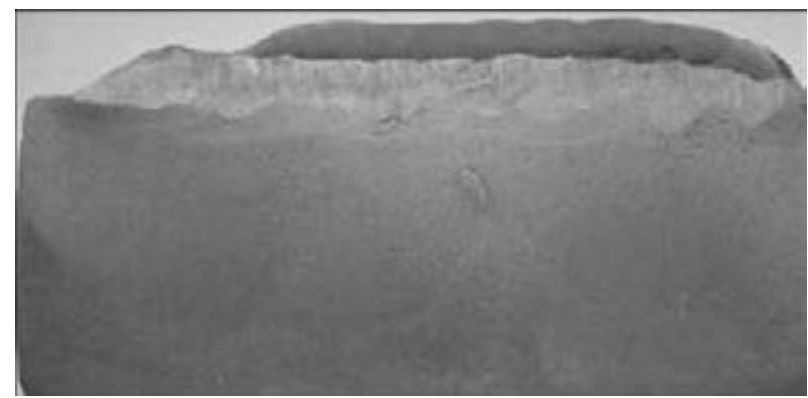

Figure 10. Macrosection of Hastelloy 6-G deposit with steel 309L buffer layer 
$200{ }^{\circ} \mathrm{C}$ in single-layer surfacing. Preheating can be increased to $400{ }^{\circ} \mathrm{C}$ in some cases.

The cooling rate of cobalt deposits is also an important criterion. In many cases martensite transformation in base metal steel leads to local stresses, which can overload the brittle deposited metal and result in cracking.

Buffer layers. The use of buffer layers allows decreasing the temperature of preheating for the coatings sensitive to cracking. As a rule, the steels based on iron, such as 309L or nickel alloys like Inconel 625, can be used for this purpose. Figure 10 shows macrosection of the cobalt-based alloy deposit with buffer layer of steel 309L produced using cobalt flux-cored wire Hastelloy 6-G.

The method of application of buffer layers affects hardness of deposited layer, therefore the control of technology is required. The selection of alloy for buffer layer depends also on need in the subsequent heat treatment.

Trends for the future. Nowadays the majority of cobalt flux-cored wires are surfaced using arc method with consumable electrode. Another method of surfacing is using the automated TIG process. Striving for higher quality and efficiency of TIG surfacing resulted in using the technology with hot wire. For this purpose the compositions of charges of flux-cored wires are optimized only for TIG process. For standard alloys, such as alloys 6 and 21, the cobalt flux-cored wires for TIG welding of $1.2 \mathrm{~mm}$ diameter already exist.

\section{Conclusion}

Today cobalt flux-cored wires have many possibilities of application in the field of surfacing of corrosion- and wear-resistant layers. High qual- ity types of deposited metal, high efficiency, economy of expenses, flexibility of compositions of alloys and excellent welding characteristics are the main arguments for their application.

1. Bouquin, B., Penning, O., Bonnel, J.-M. (2010) Herstellung von korrosionsbestaendigen Plattierungen durch Auftragschweissen mit Fuelldrahtelektroden. In: Grosse Schweisstechnische Tagung.

2. Bonnel, J.-M., Pease, N.C. (2006) Cored wires for corrosion resistant alloys: Status report 2006. In: IIW Congress Proc. (8-10.03.2006, Stellenbosch, South Africa).

3. Bonnel, J.-M, Pease, N.C. (2006) Duplex and superduplex cored wires: modern consumables for modern steel. Ibid.

4. Bonnel, J.-M., Vass, N., Pease, N.C. (2001) Fils tubulaires pour le soudage d'aciers inoxydables. In: Soudage Automatique. Applications Industrielles $d u$ Soudage avec Fil Fourre (Institut de Soudure, 11.12.2001).

5. Bonnel, J.-M. (2002) Fils fourres a poudre metallique - Journee d'etude. In: Soudage et mise en ниvre de l'acier inoxydable (Institut Belge de la Soudure, 28.11.2002).

6. Penning, O., Bonnel, J.-M., Muehlbauer, H. (2008) Basische Fuelldraehte fuer Edelstahl und Nickel-Basis-Legierungen. Das fehlende Bindeglied. In: Gross Schwesstechnische Tagung.

7. Bonnel, J.-M., Cordari, A., Desir, J.L. (2004) Fils fourres base nickel. In: SWI Seminaire Soudure (10.03.2004, Yverdon-les-Bains).

8. Bonnel, J.-M., Bouquin, B., Cordari, A. (2009) Cored wires for high quality welding of corrosion resistant alloys. In: Eurojoin 7-GNS5 (Venetia).

9. Bonnel, J.-M. Gevulde draad $M I G / M A G$ en onderpoederdek lassen van austenitisch en duplex roestvast staal.

10. (2001) Welding alloys. In: Seminarie Belgisch Instituut voor Lastechniek (Stivak en De Nayer Instituut).

11. Bouquin, B., Muehlbauer, H. (2014) Kobalt Basislegierungen in der technischen Anwendung (Verschleissschutztagung Halle).

Received 12.05.2014 